ISSN: 2224-0616

Int. J . Agril. Res. Innov. \& Tech. 8 (1): 62-69, J une, 2018

Available online at http://www.ijarit.webs.com

\title{
IMPACT OF CLIMATE CHANGE ON AGRICULTURAL PRODUCTION AND FOOD SECURITY: A REVIEW ON COASTAL REGIONS OF BANGLADESH
}

\author{
M.S. Hossain ${ }^{1 *}$ and A.K. Majumder ${ }^{2}$
}

Received 21 March 2018, Revised 12 June 2018, Accepted 26 June 2018, Published online 30 June 2018

\begin{abstract}
Bangladesh is severely vulnerable to climate change and its devastation on coastal livelihood and food security has been substantiated. Climate induced hazards will lead to food insecurity directly and indirectly by affecting the coastal biophysical and socioeconomic states. This review article found the potential impacts on coastal agricultural, livestock and fisheries sectors those are the main source of livelihood and food security to coastal people. Furthermore, most of the rural coastal people are hard poor in which women are major in portion and contribute to ensure food security for the entire family. Scrutinizing on 'vulnerability' revealed that it is not gender neutral and socio-economically underprivileged groups and marginal people are invaded disproportionately in which women is ranking in the top of the order. Hence, existing gender-poverty nexus along with socio-economic and political aspects make women more endangered to climate vulnerability and food security. It also found that existing policies and adaptation mechanisms failed to address the influence of powers on marginalize women and growing trend of feminization of food insecurity. In addition, also found the necessity for immediate pertinent caucus before the onset of this imminent concernment by aggregating gender and identified vulnerable groups.
\end{abstract}

Key words: Climate Change, Food Security, Vulnerability, Gender, Agricultural Production

${ }^{1}$ Lecturer, Department of Environmental Science, Stamford University Bangladesh, 744, Satmosjid Road, Dhanmondi, Dhaka-1209, Bangladesh

${ }^{2}$ Professor, Department of Environmental Science, Stamford University Bangladesh, 744, Satmosjid Road, Dhanmondi, Dhaka-1209, Bangladesh

*Corresponding author's email: shawpanesrm@yahoo.co.uk (M.S. Hossain)

\section{Introduction}

Our globe is warming gradually due to Green House Gases (GHGs) emission from anthropogenic activities and resulting to climate change. It has been considered as one of the forthcoming multi-faceted calamity for the global environment and society that will affect through changing in climatic variables i.e., temperature, rainfall, soil quality, drought, storm surge and sea level (Ramlall, 2014; Houghton, et al., 1996). There are many Global Climatic Models (GCM) proved the continuous ice-caps melting for global warming is the consequence of global sea level rise (SLR) that will adversely affect on the both biophysical $^{1}$ and socioeconomic ${ }^{2}$ states of our

\footnotetext{
${ }^{1}$ Biophysical vulnerability is the risk-hazard or impact-driven approaches that illustrate the risk of an event, frequency, magnitude, exposure, hazardous areas and its degree those have adverse potential impacts on environment and social systems along with the accounting of adaptation versus mitigation for decision making.

${ }^{2}$ Socioeconomic vulnerability conceives estimation of impacts generating from biophysical processes on individuals or communities in social, cultural, political, historical and economic perspectives.
}

environment and its community (Thurlow, et al., 2012). The Third and Fourth Assessment Report (AR3 and AR4) by IPCC in 2001 and 2007 brought the message to global community to be aware about $88 \mathrm{~cm}$ SLR and $1.7^{\circ} \mathrm{C}$ global surface temperature rises in this century those will impose an arduous struggle for coastal low-laying 22 deltaic countries for severely being affected their 170 million coastal people (IPCC, 2001; 2007). The devastation found from intensive pertinent studies brought it to the frontline of consideration as an important impediment for achieving Millennium Development Goals (MDGs) and sustainable development.

The studies on assessment of socioeconomic impacts of SLR found its potential threat to agricultural production and how the important factors i.e., increase or decrease rainfall, cyclone, flood, storm surge salinity intrusion, drought, land degradation, crop diseases, soil fertility etc are interlinked with SLR and endangering food security (Stern, 2006; Pender, 2008). Although food security has already taken as an important social sustainability indicator because of global experiences of almost $12 \%$ of global population suffering from hunger, 700 million from 
malnutrition, famine vulnerability to tens of millions people and hundreds of millions children from stunned, wasted and under-weight condition (Chen and Kates, 1994) but climate induced problems acting as significant retardation and making it more labored. The relevant study conducted by Pender (2008) found its potential risk to additional 30 to 200 million and 250-550 million people for increasing $2^{0}$ and $3^{\circ} \mathrm{C}$ in Africa and Asia. In this situation, FAO (2008) assumed to be influenced of world's 25\% cropland that will terribly endanger food security.

In present days, impacts of climate change on food security is a hot topic for developing countries but presently called the attention of global communities. The global concerns on it are helping to promote the integrated and multidimensional activities through strategic management and implementation for ensuring food security (Daina et al., 2008). In essence, although climate induced catastrophes are taken into consideration in government, nongovernment and research activities for planning and development but understanding of vulnerable people is still questioned. Local people are not sound to how climate change affects socioeconomic and environmental systems. Adaptation is undoubtedly important for achieving food security in the coastal zones but not practicing owing to lack different sectoral amalgamation, administrative reluctant and procrastination, ignoring climate variability, impacts and capacity building techniques in formal educational systems. The inadequate knowledge and understanding, environmental, technological, socio-economic conflicts and changes, gender inequality, lack of scientific decisions on different changes can create a hard obstacle for diverse strategic adaptive measures for food security (Chen and Kates, 1994). A key challenge is therefore to find ways to improve adaptation by both poor and rich, young and old, and the powerless and the powerful not only to a changing climate but also to other continuing changes in society, technology, and the environment. If this challenge can be met, it will help to balance the threat posed by climate change with the hope of a better world for all (CCC, 2009).

Bangladesh is a low-laying landmass which floodplains occupying $80 \%$ with mean elevation of less than 1 meter on tidal floodplains, on the main river and estuarine floodplains 1 to 3 meters, and up to 6 meters on hilly regions from sea level. Consequently, coastal zones are in the 'front line' to climate change vulnerability and threat to natural, social and economic systems. According to IPCC (2007), its quarter of total population directly or indirectly dependant on $15 \%$ of coastal for their daily livelihood but 2-3 $\mathrm{mm}$ increase in sea surface level during the firsthalf of 21 st century will create 30 million environmental refugees in this country (Harasawa, 2006). As a result, social marginal people i.e., women, children, minority and hard poor people bear the brunt of extreme sufferings.

Bangladesh has taken different adaptation measures incorporated in their policies for decision-making for all vulnerable i.e., women, poor, children, old, powerless and ethnic groups to achieve national food sufficiency (Bala and Hossain, 2009; CCC, 2009). Besides, awareness and adaptation measures are needed to prioritize these groups as well as alternative income generation sources (Röhr, 2006; Pender, 2008). Furthermore, adequate relevant information regarding these groups along with local knowledge, health and wealth status, affordability and availability, skills and political power relations are important to take into account for determining vulnerability levels and shaping the 'bounce back' potentials (CCC, 2009). Good governance with social safety net programs is immediately requisite for marginal vulnerable people to ensure food security and achieve all MDGs (Roksana et al., 2014).

\section{Impacts of climate change on agricultural production in Bangladesh}

Bangladesh lies in the northeastern part of South Asia between 20034' and 26038' N latitude and $88^{\circ} 01^{\prime}$ and $92^{\circ} 41^{\prime} \mathrm{E}$ longitude, one of the most densely populous countries (1033.5/ sq.km) which $93.6 \%$ land and $6.4 \%$ is water resources, respectively. It is an agro based country which $20.0 \%$ of national GDP comes from agricultural production and employing $65.0 \%$ of total labor force in 2010 (Ruane et al., 2013). Consequence of climate change, this sector of north-eastern districts is suffering from increased spikelet sterility, higher infestation of pests and diseases, deficiency of water and soil moisture due to increase rate of evapo-transpiration and hampering the agricultural productions (rice, wheat, pulses, rape seed and coconut). On the other hand, southern coastal belt will be inundated and vulnerable for salinity intrusion causing to reduce the existing crop productions. The $700 \mathrm{~km}$ long coastline of Bangladesh covers 2.5 million ha area in coastal area is supporting to 35 million people as their home and daily livelihood and expected to be reached to 40-50 million by 2050 (Agrawala et al., 2003; Ahamad et al., 2012). But 0.83 million ha land within these areas are vulnerable to sea level rise, suffering from salinity intrusion varying from 0 to $20 \mathrm{ppt}$ deteriorating agro-resources and the distribution is gradually increasing (Uddin et al., 2011). Consequently, agricultural production is decreasing $(0.3 \mathrm{~m}$ rise will cause a net reduction of 0.5 million metric tons) due to shortage of fresh water, soil degradation and terminative energy and germination rate of some plants (Krishnamurthy et al., 2014). A recent research showed within 8.3 million ha there is 4.2 million 
ha of lands are droughts prone with different intensities. At present, 30 million tons food are producing yearly from irrigated agriculture (56.0\%) in which $80.0 \%$ areas are irrigated from groundwater due to terrible shortage of surface and ground waters where eastern part will be suffered from loss of 14,000 tons grain production alone in 2030 and 252,000 tons by 2075 (Islam et al., 1999; Minar et al., 2013). The recent studies found that climate change causing the change in rainfall pattern will decrease $30.0 \%$ crop production in 2100 and $28.0 \%$ for rice and $68.0 \%$ for wheat respectively (Karim et al., 2012). Furthermore, 1 meter sea level rise will lose up $15.0 \%$ of total land area that will create up to 30 million environmental refugees and also national GDP will decline between 27.0-57.0\% (Agrawalaet al., 2003; Harasawa, 2006).

\section{Impacts on food security in Bangladesh}

According to FAO (2008), food security stands for four basic pillars such as availability, access for all people, utilization and stability. Climate change is playing a key driver in developing countries by affecting their socio-economic, temporal, political aspects from the national to global levels. There are several vulnerability assessment studies found the impacts of climate change in Bangladesh, on its natural systems through low land inundation, storm surges, decreasing river flows, saline water intrusion and change in coastal morphology (Huq and Ayers, 2007) resulting to increase risk of natural disasters (cyclone, tornados, storm surges, flush flood, landslide, drought, erosion, erratic heavy rainfall), drought and erosion, sedimentation of riverbeds etc. Consequently, socio-economic systems are adversely affecting by loss and transformation of thousands of hectares cultivable crops land from non-flood prone to moderately or extremely flood-prone status and livelihoods of local communities endangering food security.

\section{Effects on availability}

According to FAOSTAT (2012), Bangladesh's $70.0 \%$ of landmass using for agricultural purposes and rich cultivation contributes almost $95.0 \%$ of total cereal production. Although there is a remarkable increase in cereal production from 10 million metric tons (MT) of 1970s to 30 MT in 2001 but warning about climatic factors for creating sensitivity and challenges on overall production. Coastal areas of Bangladesh are occupying more than $30.0 \%$ of net cultivable land which constitutes the $52.5 \%$ (0.828 of 2.85 million hectares) for net cultivable area (Paul and Rashid 1993). But, the expected $30 \mathrm{~cm}$ and $50 \mathrm{~cm}$ SLR by 2030 and 2050 will lead to loss up to $3.0 \%$ and $6.0 \%$ of coastal agricultural lands in the respective years (Tanner et al., 2007) along with displacing 35 million coastal people and declining
8.0-17.0\% of rice production (IPCC, 2007). Flood is another most considerable factor for agricultural production loss. Mirza (2011) stated the devastation of foods as annually $20.0 \%$ of landmass flooded in Bangladesh and can be extended to $70.0 \%$ in extreme cases. Ahmed (2006) argued that climate change would affect $18.0 \%$ of low-lying area and imperil $12.0-16.0 \%$ of new areas to high intensity flood risk along with increasing yearly $25.0 \%$ to $39.0 \%$ flood prone areas. Paul and Rashid (1993) showed an average of 0.5 MT rice productions was lost in every year during 1962-1988 that was equivalent to $30.0 \%$ of national food imports. Coastal 6 million people are already suffering from high salinity ( $>5 \mathrm{ppt}$ ) and SLR will lead it to increase 13.6 million in 2050. There are 1 million ha of net cultivable land areas have been affected by salinity intrusion and annually 659,000 MT rice productions could be lost (Paul and Rashid, 1993). Ahmed (2006) estimated the rainfall scenarios on the basis of changing climatic condition and found the increase in average rainfall by $10.0-15.0 \%$ in 2030 s and $27.0 \%$ in 2075 s in summer season that will render to the severe floods. Besides, land erosion and siltation is a severe problem to 1200 $\mathrm{km}$ river-bank areas and annually 8,700 ha are being lost (Ahmed, 2006) that gave the experiences of declining $1.2 \%$ agricultural production yearly during 1969-1994. Cyclone is another devastation of climate change, which is affecting the agricultural system and livelihood in almost every year.

\section{Effects on access}

Access to food refers to the physical, economic, safe and nutritious food with self-sufficiency. Bangladesh is a poor country, which most of the people are living on rice and fish for their dietary and poverty is the main cause of food in security. Mirza (2011) investigations revealed the food access of Bangladesh is dependent on family size, earning person, daily wage, buying capacity, food supply, market mechanisms, inflation rate and government policies toward the agricultural systems, gender, classes, races, climatic locations and vulnerabilities. In spite of socio-economic constraints, it already achieved daily 2, $2122 \mathrm{kcal}$ (upper poverty line) and 1,805 kcal (lower poverty line) food consumption requirements for every people recommended by FAO $(1,800$ $\mathrm{kcal} /$ day). However, it is not still self-sufficient in food production for the whole population. Based on rapid growing population, its food-grain requirement will be 41.6 MT in 2030 and more 14.64 MT additional productions would be needed to be self-sufficient. But adverse effects of climate change on agricultural production and coastal livelihood will make it more difficult to achieve. According to FAO (2008) almost $60.0 \%$ farmers are landless and $20.0 \%$ unable to buy food for their entire families over the year. The loss of food production, land and livelihood will 
affect the economic access to food. Ahmed (2006) estimated the loss to physical infrastructure by these events where 5,212 and 1,682 kilometers of hospitals and health centers will be damaged in which floods will alone be responsible for 1011 and 3,315 kilometers in 2030 and 2050 respectively. As a result, rural food unavailability in market could be increased due to improper supply of food.

\section{Effects on stability}

In coastal Bangladesh, stability is challenged for declining agricultural land and limited access to water, energy and food. Climatic hazards like floods, cyclones, salinity, storms and erosion are exposed to more vulnerable to achieve food security. Roksana et al. (2014) stated that high inflation rate and rapid rice prices go up from 2005 to 2008 increased $8.5 \%$ poverty in Bangladesh. Stability would be multi-dimensional approaches that will come from every side of government, NGO and local community. It is necessary to support from the government for vulnerable people by financial assistance, training on scientific cultivation, proper fertilization, promoting research for high yielding, aware on climate change, introducing the salt tolerant rice species, controlling volatility, trade restrictions, and advance weather forecasting. Capacity building and awareness program by NGOs along with improving in water and sanitation systems for marginal people will play important role for food stability. Community can practice the adaptive measures, and cultivate the more seasonal, water and soil friendly crops to get rid of or minimize the climate vulnerability.

\section{Effects on utilization}

The effects of climate change on food utilization are reflected through the availability, accessibility and stability (Akudugu and Alhassan, 2013).The effects of climate change drivers will influence the sufficient food production, affordability and stability in coastal regions. Poor food utilization will be occurred due to malnutrition, stunned, under weight and other climate induced water borne diseases. According FAOSTAT (2012), 65\% of total income is spent for buying food in which half goes for rice, still $25 \%$ of people are undernourished and 19\% have limited access to water. According to Vulnerability Analysis and Mapping (VAM) of World Food Program (WFP) malnutrition in Bangladesh is not carried out for poverty while lack of knowledge, awareness and cultural practices are the determinants. But it is still a problem in the rural coastal areas due to poor access to pure drinking water and safe sanitation system. Floods, cyclones and storm surges completely destroy the poor potable water and sanitation systems those are responsible for water borne diseases (FAO, 2008) and snatch huge toll to rebuild these systems (Ahmed, 2006).
Women, hard poor and children are highly vulnerable to these events.

\section{Climate vulnerability, gender and food security}

Food security in developing countries is complex, multifaceted, interlinked and intertwined with different socio-economic and political aspects (Mirza, 2011). Although bio-geophysical effects of climate vulnerability on Bangladesh brought out significantly but unfortunately socio-economic, environmental aspects along with vulnerable groups and gender issues have not reflected or scrutinized significantly in research and developmental initiatives (Ericksen et al., 1996; Asaduzzman et al., 2005). The study on specific gender analysis found that climatic hazards invade disproportionately to the socioeconomically underprivileged groups such as infant and children, women, hard core poor, farmer, fisherman, day labor, low caste, ethnic minorities, physically disable and old people. Among these groups and marginal people vulnerability to women is ranking in the top of the order and their coping efforts are severely determined by local handicapped power structure of the society. In such way, 'gender analysis' is using as an important approach to understand the climate induced impacts on individuals and suggest the best strategies to be in practice. Nevertheless, gender issues were ignored utterly by global community in the massive climatecoping initiatives such as Kyoto Protocol and UN Framework Convention on Climate Change (UNFCCC) (CCC, 2009).

Global gender-poverty nexus represents women as the $70 \%$ of global total poor people living under poverty line and their vulnerability levels are dependent on their social-economic identity such as race, ethnicity and age (Enarson and Hearn, 1998; Pender, 2008). Reid et al. (2007) figured out the women vulnerability to climate change in socio-economic and techno-political aspects due to gender inequalities that resulting limited access to information, credit, resource and property, neglecting participation and ignoring for decision making, improper income and food distribution etc. In Asia, women are homemaker and take the liability to supply household food, safe drinking water and constantly feeding family members even by skipping their meals (RVCC, 2003). Furthermore, their importantly influence the household food security and children nourishment (Mohammad and Karim, 2007). The extreme events will affect their three major livelihoods such as agricultural, livestock and fisheries sectors those will cause to high jeopardy of socio-economic disasters, health problems and national food security (Bank, 2000; Asaduzzman et al., 2005). 
Climate change is prevailing the nexus of food insecurity and poverty in the coastal zones of Bangladesh. Consequently women, poor, children and marginalized people suffer extremely in such hostile environmental circumstances and substantiated victims to food insecurity and its ill-effects (Uraguchi, 2010). Uddin (2012) found that coastal marginal farmers are most vulnerable to food insecurity and usually affected by least change in crop, fish and livestock firming. Further, wealthier households in the coastal regions are more optimistic for next year food security than poor people which also reflected the same scenario for higher and lower socioeconomic status people (Fuster et al., 2008). In most cases, loss bearing adaption strategy is barely impossible for marginal coastal people (Ahmed, 2006) that affect women and children appallingly by decreasing food intake, force them to sell their land and livestock and push to migrate or become day laborer and/or prostitute (CCC, 2009; Pender, 2008).

Climate change is multiplying the crisis by declining cultivated land and inaccessibility to fresh water supply. At the same time natural disaster increase the vulnerability and affect the socio-economic patterns of the victims and increase food crisis especially in the coastal and rural areas (Raillon, 2010). It is not gender neutral and plays as an important indicator to assess vulnerability, food crisis and health hazards on women who are the most vulnerable to disasters. Women comprise half of the total population in Bangladesh in which $80.0 \%$ are living in the rural areas (Dankelman et al., 2008). These rural women are contributing to food production and supply by engaging their livelihood with different socio-economic activities such as agricultural practices, goat farming and cow rearing and fattening, weaving and handicrafts etc. (Parvin and Ahsan, 2013). Unfortunately, most of them are hard poor and severely vulnerable to climate change. Besides poverty, socio-economic and political aspects make women more endangered to climate vulnerability and food security (FAO, 2008).

Climate related policies and adaptation mechanisms of Bangladesh are not gender neutral. Government policies have largely failed to address the complexity of the intersecting power relations that marginalize women and men differently (Arora-J onsson, 2011; J abeen, 2014) and growing trend of feminization of food insecurity (Manoj, 2012). Therefore, immediate pertinent policies are needed before the onset of this imminent concernment (Fan, 2010; Uraguchi, 2010). Hence gender aggregated research are rationally needed to identify specific vulnerable groups especially on women for achieving food security (Nirmala and Venkateswarlu, 2012).

\section{Discussions and Conclusions}

The large and socio-economically important coastal regions of Bangladesh are highly vulnerable to impacts of climate change. The consequences of global change is adversely affecting biophysical systems of these regions by low land inundation, intense flood, cyclone and storm surge risks along with socio-economic conditions specially daily livelihood and food security through increasing in sea level, temperature, salinity intrusion, decrease soil fertility, declining cultivable landmass, destroying safe water and sanitation systems, infrastructure, plant diseases, terminative energy and germination rate of some plants and reducing agricultural productivity. In Bangladesh where agriculture is the largest sector of the economy, but it is under pressure from increasing demands for food. Because the economy and food supply are so closely linked to climate, significant variations in climatic events have profound effects on society.

In these circumstances, climate can be thought of as a hazard, rather than a resource especially for coastal regions where most of marginal farmers, women and children are exposed to climate vulnerability in terms of both health and food security. These climatic induced hazards will multiply the food and pure water crisis by declining arable land and inaccessibility. Damage of agricultural land will decrease the crop production and livelihood; consequently, coastal poor people will suffer from both food crises and/ or insolvency aspects. Continuous rising food prices creating harder obstacle to economically access to food and increasing the food-insecurity. Loss of infrastructure influences the transportation of food supply and distribution. Coastal areas are considered as the rice deficit pocket. Most of the people don't have sufficient knowledge on climate vulnerability, food security and hygienic water and sanitation systems. The climatic hazards will affect the extreme condition of these marginal coastal people and achieving food security will be more difficult. The overall conceptual impacts of climate change on agricultural production and food security in the coastal regions of Bangladesh are shown in Fig 1.

Food security is a complex, interdependent and multidimensional concept where climate change is playing a vital determinant to achieve it. Although Bangladesh has already achieved food availability but still is suffering from undernourishment due to lack of knowledge and awareness on food habit. To achieve it, a bunch of initiatives are prerequisite from government, non-government and community levels. Government safety nets in policy implementation, market monitoring and controlling volatility could be effective efforts. Bangladesh also needs long-term strategy for 
dealing with climate vulnerability through increasing agricultural productivity and ensuring food security. Diversified cultivation practices with newly introduced species should be promoted for achieving long term self-sufficiency. Awareness and knowledge building program can be introduced to change habit of in-taking, cooking, processing food to get of malnutrition in the rural areas.

The adverse impacts of climate change on food security have been taken in consideration as an inevitably important driver to achieve MDG for restoring the ecosystem and ensuring the food to the vulnerable communities for sustainable development. The comprehensive goal to achieve for food security will be more helpful for being aware, skilled, empowered and changing local stakeholders to their sustainability. The integration of different level of government with international collaboration and cooperation in policy making would be the right practice for ensuring future food security in coastal regions of Bangladesh.

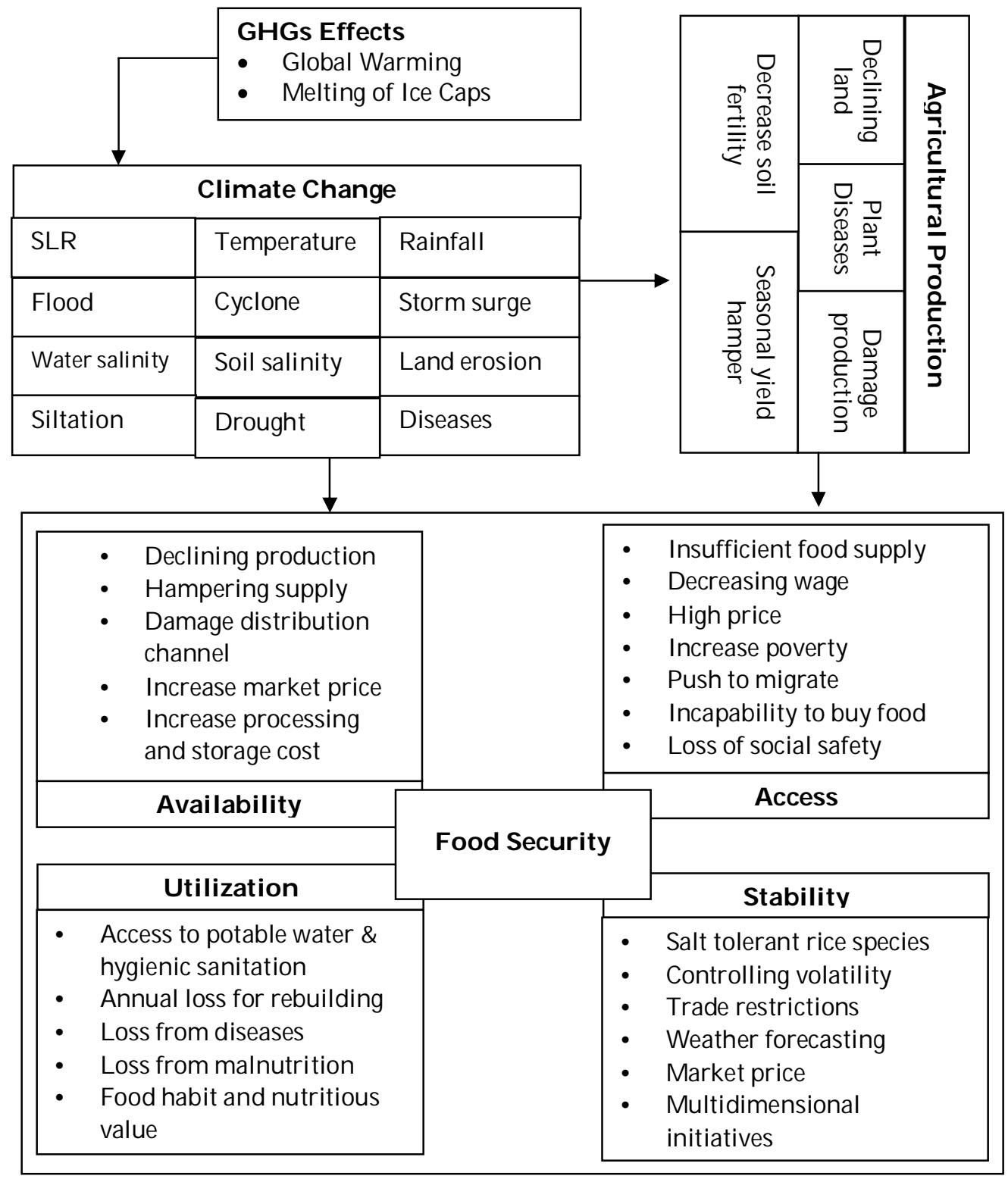

Fig. 1. Showing the impacts of climate change on agricultural production and food security. 


\section{References}

Agrawala, S., Ota, T., Ahmed, A.U., Smith, J. and Aalst, M.V. 2003. Development and Climate Change in Bangladesh: Focus on Coastal Flooding and The Sundarbans. Paris, France, Organization for Economic Cooperation and Development. COM/ENV/EPOC/DCD/DAC(2003)3/ FINAL $34 \mathrm{p}$.

Ahamad, M.G., Khondker, R.K., Ahmed, Z.U. and Tanin, F. 2012. Seasonal food insecurity in Bangladesh: evidences from northern areas. Mitigation and Adaptation Strategies for Global Change. 18 (7): 1077-1088.

Ahmed, A.U. 2006. Bangladesh: Climate Change Impacts and Vulnerability, A Synthesis. Department of Environment, Climate Change Cell. Dhaka, Bangladesh, Comprehensive Disaster Management Programme. $23 \mathrm{p}$.

Akudugu, M.A. and Alhassan, A.R. (2013. The Climate Change Menace, Food Security, Livelihood and Social Safety in Northern Ghana. Int. J. Sust. Dev. World Policy. 1(3): 80-95.

Arora-J onsson, S. 2011. Virtue and vulnerability: discourses on women, gender and climate change. Global Environmental Change. 21 (2): 744-751.

Asaduzzman, M., Ahmed, A.U., Haq, E. and Chowdhury, S.M.Z.I. 2005. Climate Change and Bangladesh: Livelihoods Issues for Adaptation. Dhaka, Bangladesh, Bangladesh. Institute for Development Studies (BIDS). $17 \mathrm{p}$.

Bala, B.K. and Hossain, M.A. 2009. Food security and ecological footprint of coastal zone of Bangladesh. Environ. Dev. Sust. 12(4): 531545.

Bank, W. 2000. Bangladesh: Climate Change and Sustainable Development. Dhaka, Bangladesh, Rural Development Unit, South Asia Region. $95 \mathrm{p}$.

CCC. 2009. Climate Change, Gender and Vulnerable Groups in Bangladesh. Dhaka, Bangladesh, Climate Change Cell, DoE, MoEF; Component 4b, CDMP, MoFDM. 80 p.

Chen, R.S. and Kates, R.W. 1994. Climate change and world food security. Global Environ. Change. 4 (1): 3-6.

Daina, P., Santiago, G.A. and Manuel, B.J 2008. Model on food security in developing countries: A systemic perspective. International conference of the system dynamics society. D. Brian C. Athens, Greece, The System Dynamics Society. $55 \mathrm{p}$.

Dankelman, I., Alam, K., Ahmed, W.B., Gueye, Y.D., Fatema, N. and Menasaj-Kutin, R. 2008. Gender, climate change and human security lessons from Bangladesh, Ghana and Senegal. In: Grossman, A. and Owren, C. (Eds), ELIAMEP. Dhaka, Bangladesh,
Women's Environment and Development Organization. $49 \mathrm{p}$.

Enarson, E. and Hearn, M.B. 1998. The Gendered Terrain of Disaster: Through Women's Eyes. Praeger, Westport, U.S.A.

Ericksen, N.J., Ahmad, Q.K. and Chowdhury, A. R. 1996. Socio-economic Implications of Climate Change for Bangladesh. In: R.A. Warrick and Q.K. Ahmad (eds), The Implications of Climate and Sea-level Change for Bangladesh. Dordrecht, The Netherland, Kluwer Academic Publishers. $205 \mathrm{p}$.

Fan, S. 2010. Policy for food security with marginal people priority. Washington, USA, Bangladesh. Food Security Investment Forum. $2 \mathrm{p}$.

FAO. 2008. Climate Change and Food Security: A Framework Document. Rome, Italy, Food and Agriculture Organization of the United Nations. Retrieved from : www.fao.org/ forestry/ 15538-

079b31d45081fe9c3dbc6ff34de4807e4.pdf (access on October 18, 2014).

FAOSTAT. 2012. Food and Agriculture Organization (FAO) statistics, United Nations. $\quad$ Retrieved from http:// faostat.fao.org/ (access on October 19, 2014).

Fuster, M., Mutonyi, M., Houser, R.F. and Coates, J. 2008. Factors Associated with Food Security Optimism in Bangladesh. J. Hunger Environ. Nutr. 3 (1): 84-99.

Harasawa, H. 2006. Key vulnerabilities and critical levels of impacts on east and southeast Asia, in Avoiding Dangerous Climate Change. In: Schellnhuber, H.J. et al., Cambridge, Cambridge University Press. $133 \mathrm{p}$.

Houghton, J.T., Meira, F.L.G., Callander, B.A. Harris, N., Kattenberg, A. and Maskell, K. 1996. Climate Change 1995: The Science of Climate Change, Contribution of Working Group I to the Second Assessment Report of the Intergovernmental Panel on Climate Change. England: Cambridge University Press., Cambridge. 7 p.

Huq, S. and Ayers, J. 2007. Climate Change Impacts and Responses in Bangladesh. Brussels, Policy Department Economy and Science, EU. $7 \mathrm{p}$.

IPCC. 2001. Climate Change 2001: Impacts, Adaptation, and Vulnerability, Contribution of Working Group II to the Third Assessment Report of the Intergovernmental Panel on Climate Change. Cambridge University Press, Cambridge. $31 \mathrm{p} \& 177 \mathrm{p}$.

IPCC. 2007. Climate change 2007: Impacts, adaptation, and vulnerability, Contribution of Working Group II to the Fourth Assessment. Cambridge University Press, 
Cambridge, The Intergovernmental Panel on Climate Change. $414 \mathrm{p}$.

Islam, S.M.R., Huq, S. and Ali, A. 1999. Beach Erosion in the Eastern Coastline of Bangladesh. Vulnerability and Adaptation to Climate Change for Bangladesh. pp. 71 - 92. In: S. Eds. Huq, Karim, Z., Asaduzzaman, M. \& Mahtab. London: UK, Kluwer Academic Publishers.

Jabeen, H. 2014. Adapting the built environment: the role of gender in shaping vulnerability and resilience to climate extremes in Dhaka. Environment and Urbanization. 26(1): 147165.

Karim, M.R., Ishikawa, M., Ikeda, M. and Islam, M.T. 2012. Climate change model predicts $33 \%$ rice yield decrease in 2100 in Bangladesh. Agron. Sust. Dev. 32 (4): 821830.

Krishnamurthy, P.K., Lewis, K. and Choularton, R.J. 2014. A methodological framework for rapidly assessing the impacts of climate risk on national-level food security through a vulnerability index. Global Environmental Change. 25: 121- 132.

Manoj, M. 2012. Price Hikes and The Feminization of Food Insecurity in Bangladesh. Women \& Environments International Magazine. Toronto, Canada, Faculty of Environmental Studies, York University. Fall 2011/Winter 2012. pp. 2122.

Minar, M.H., Hossain, M.B. and Shamsuddin, M.D. 2013. Climate Change and Coastal Zone of Bangladesh: Vulnerability, Resilience and Adaptability. Middle-East J. Sci. Res. 13 (1): 114-120.

Mirza, M.M.Q. 2011. Climate change, flooding in South Asia and implications. Regional Environmental Change. 11(1): 95- 107.

Mohammad, A.R. and Karim, T.M.M. 2007. Does women's status matter for food security? Evidence from Bangladesh. UNU-WIDER, United Nations University (UNU). 1p.

Nirmala, G. and Venkateswarlu, B. 2012. Gender and climate resilient agriculture: an overview of issues. Current Science. 103 (9): 987-988.

Parvin, G.A. and Ahsan, S.M.R 2013. Impacts of climate change on food security of rural poor women in Bangladesh. Management of Environmental Quality: An International Journal. 24 (6): 802-814.

Paul, B. and Rashid, H. 1993. Flood damage to rice crop in Bangladesh. The Geographical Review. 2 (83): 151-159.

Pender, J.S. 2008. What Is Climate Change? And How It Will Effect Bangladesh. Dhaka, Bangladesh, Church of Bangladesh Social Development Programme. Briefing Paper. (Final Draft). 12 p.
Raillon, C. 2010. Bangladesh, Climate Disasters Humanitarian Practice Challenged by Populations "Resilience", Geoffroy, V. D. Khulna, Bangladesh, Urgence Rehabilitation Development. $14 \mathrm{p}$.

Ramlall, I. 2014. Gauging the impact of climate change on food crops production in Mauritius. Int. J. Climate Change Strat. Manage. 6 (3): 332-355.

Reid, H., Simms, A. and Johnson, V. 2007. Up in smoke? Asia and the Pacific: The threat from climate change to human development and the environment. London, UK, New Economics Foundation. $7 \mathrm{p}$.

Röhr, U. 2006. Gender and climate change. Tiempo. 59: 3-7.

Roksana, F., Jalil, M.A. and Alam, M.M. 2014. Strategic Approaches to Food Security in Bangladesh. J. Econ. Sust. Dev. 5 (1): 42-50.

Ruane, A.C., Major, D.C., Winston, H.Y., Alam, M., Hussain, S.G., Khan, A.S., Hassan, A., Tamim, B.M.A.H., Goldberg, R., Horton, R.M. and Rosenzweig, C. 2013. Multi-factor impact analysis of agricultural production in Bangladesh with climate change. Global Environ. Change. 23: 338- 350.

RVCC. 2003. Community Level Vulnerability Assessment Conducted in Southwest Bangladesh. CARE Bangladesh, Dhaka, Bangladesh, Reducing Vulnerability to Climate Change (RVCC) Project. 14 p.

Stern, N. 2006. Report of the Stern Review: The Economics of Climate Change. London, HM Treasury. $83 \mathrm{p}$.

Tanner, T.M., Hassan, A., Islam, K.M.N., Conway, D., Mechler, R., Ahmed, A.U. and Alam, M. 2007. ORCHID: Piloting Climate Risk Screening in DFID Bangladesh. University of Sussex, United Kingdom, Institute of Development Studies. 49 p.

Thurlow, J., Dorosh, P. and Yu, W. 2012. A Stochastic Simulation Approach to Estimating the Economic Impacts of Climate Change in Bangladesh. Rev. Dev. Econ. 16 (3): $412-428$.

Uddin, M.E. 2012. Household Food Security Status of Marginal Farmers in Selected Storm Surge Prone Coastal Area of Bangladesh. The Agriculturists. 10 (1): 98103.

Uddin, M.S., Khan, M.S.I., Talukdar, M.M.R., Hossain, M.I. and Ullah, M.H. 2011. Climate Change and salinity in Bangladesh: Constraints and Management Strategy for crop production. Rajshahi Univ. J. Environ. Sci. 1: 13-20.

Uraguchi, Z.B. 2010. Food price hikes, food security, and gender equality: assessing the roles and vulnerability of women in households of Bangladesh and Ethiopia. Gender \& Development. 18 (3): 491-501. 